Article

\title{
Sustainable Solutions for Wearable Technologies: Mapping the Product Development Life Cycle
}

\author{
Olga Gurova ${ }^{1, *} \mathbb{0}$, Timothy Robert Merritt ${ }^{2}$, Eleftherios Papachristos ${ }^{2} \mathbb{D}$ and Jenna Vaajakari ${ }^{1}$ \\ 1 Department of Culture and Learning, Aalborg University, 9220 Aalborg, Denmark; \\ jenna.vaajakari@gmail.com \\ 2 Department of Computer Science, Aalborg University, 9220 Aalborg, Denmark; merritt@cs.aau.dk (T.R.M.); \\ papachristos@cs.aau.dk (E.P.) \\ * Correspondence: gurova@hum.aau.dk
}

Received: 6 August 2020; Accepted: 9 October 2020; Published: 14 October 2020

\begin{abstract}
Wearable technologies involve the integration of technology into clothing or accessories to bring new functionalities for people on the move. Many examples of wearables are emerging, from simple fitness tracking watches to electronics deeply embedded into garments for multi-touch sensing and control for personal music players. Without careful development, wearables can have a negative impact on the environment due to increased production of electronic components, increased e-waste from abandoned devices, and increased energy usage. We examine environmental sustainability issues through a review of recent research and cases across three broad areas including the fashion industry, information and communications technology (ICT), and wearable technologies. In the analysis, we examine stages in the product life cycle and identify the unique issues for each sector, including the extraction of materials, production process, distribution of products, use, and disposal of products that have reached the end of their life. The findings are gathered as implications for design so that researchers, educators, designers, developers, and product managers will gain an overview of the issues related to environmental sustainability. Related examples of products and prototypes are provided to enable informed choices during the design and development of wearables that are more environmentally sustainable.
\end{abstract}

Keywords: sustainability; wearable technology; design; fashion; ICT; closed-loop design; design implications

\section{Introduction}

The past two decades have experienced a rapid proliferation of various consumer targeted high-tech products [1]. Along with personal mobile phones and computers, a new rapidly developing category of consumer electronics has emerged in wearable technologies, or simply "wearables". On a general level, wearable technology can be understood as the integration of technology into fibers, textiles, or garments [2]. Examples of wearables include accessory-based devices such as smart watches, glasses, and activity trackers, among others. As they become more widely adopted, wearables are expected to have a major impact on individuals' everyday lives, social institutions, and the functioning of the society as a whole [3,4]. According to Statista's Global Consumer Survey [5], the market for wearables has been steadily increasing into 2020 as wearables not only appeal to athletes or people with health concerns, but to regular consumers, as well. The pandemic [6] as well as data theft, legal regulations, and the costs of development [5] restrain its growth at the moment, but the industry anticipates further growth in the near future [5]. The same survey [5] showed that in the year 2019, $57 \%$ of wearables consumers were women while $43 \%$ were men. Also, wearables were most popular among people 25-34 years old $(36,4 \%)$ and least popular among the older population of 55-64 (6.1\%). People with medium income bought wearables more often (41\%) than those with low (34\%) or high 
$(25 \%)$ income. Despite the increasing interest toward wearables, skepticism is still expressed about whether wearables will ever meet expectations and be adopted by consumers on a large scale (e.g., [7]). Despite optimistic predictions about the explosive increase of demand in wearable technology, growth in the market has instead come at a slower pace [8]. Just as the introduction of smart watches and fitness trackers expanded the market and drove consumer demand in the past, the market for wearables still relies on companies to unlock consumer demand with innovative products.

Nevertheless, wearable technology is a vibrant area of research and development. Following the development of wearable technology, the connections between wearable computation and the field of fashion have become stronger. Whereas previously the primary focus had been on utility and functionality, researchers of wearables are now increasingly directing their focus toward aesthetics, style and fashion statements, and their role in product design [9-11]. Since wearables are worn on the body in the same way as clothes and accessories, they are more likely to be experienced as an extension of the body and self than as a separate object (if compared to portable consumer electronics, such as smartphones) [4]. Hence, it is suggested that the design of wearables should also follow changing fashion trends and practices in order to be accepted by consumers [10] as well as to achieve commercial success. Alternative terms, such as "fashionable technology" or "fashionable wearables", have emerged and are often used interchangeably with "wearable technologies" [2]. Sabine Seymour, a designer who originally coined the term "fashionable technology", defines fashionable wearables as "designed garments, accessories, or jewelry that combines aesthetics and style with functional technology" [12]. Many examples of such concepts can be found in academic research, including shape-changing fashion [13,14], a light emitting t-shirt [15], an ultra-violet (UV) light-detecting winter jacket [16], a color-matching smart watch [10], handbags with integrated displays [17,18], and jewelry that utilizes augmented reality [19]. Fashion companies and brands have been eager to explore new design opportunities offered by integrated technology. Topshop, for instance, has initiated an innovation program that aims to bring affordable wearable technology to the high street [20], while brands like Hugo Boss, Tommy Hilfiger, and Michael Kors have all recently published their own versions of smart watches [21].

As fashion practices are increasingly integrated into the design of wearables and the field is moving more closely toward the apparel industry, concerns about unintended side effects and sustainability have risen [22], making the link between wearables and sustainability an issue that needs to be explored.

\section{Environmental Sustainability and the Role of Designers}

The United Nations Environment Programme defines sustainability as "development that meets the needs of the present without compromising the ability of future generations to meet their needs. It is a visionary plan that calls for integration of economic development, social equity, and environmental protection" [23]. This understanding of sustainability is based on the "triple bottom line" principle [24], according to which sustainability consists of three different dimensions-people (social), profit (economic), and planet (environmental)—that should all be in balance. The social dimension refers to conducting beneficial and fair practices in dealings with labor, human capital, and the community. Examples of these practices may include fair wages and health care coverage to employees [25] (p. 8). The economic dimension refers to the impact of business practices on the economic system; it pertains to the capability of the economy as one of the subsystems of sustainability to survive and evolve into the future in order to support future generations [25] (p. 8). The environmental dimension refers to engaging in practices that do not compromise the environmental resources for future generations. It pertains to the efficient use of energy resources, reducing greenhouse gas emissions, and minimizing the ecological footprint [25] (p. 8). While we acknowledge that wearable technologies create unique concerns for all the dimensions of sustainability [24]—social, economic, and environmental-in this paper we have decided to focus solely on environmental sustainability. By choosing this angle, we contrast and compliment the approach by Lee and colleagues [7], who focused on social sustainability and the role of wearables in improving well-being and quality of life. The economic angle is left for future research, as is a synthetic approach that would consider all three dimensions. 
Existing studies on wearables and sustainability have revealed the following concerns. If wearables proliferate and are adopted by consumers without sustainability taken into account, they will end up being just another short-lived and mass-consumed product category contributing to global resource depletion and e-waste accumulation [1]. It is feared that combining electronics with textiles will intensify aesthetic, technical, and functional reasons for product obsolescence [1]. As a matter of fact, it has already been evidenced that existing wearables have a relatively short life cycle, as, according to a research, every third American consumer who owned a wearable product stopped using it within six months [7]. This short life cycle of wearables creates concerns for sustainability. Moreover, according to some studies, current wearable technologies do not fully meet users' expectations and needs [26-28]. Unattractive design, useless functions, and difficulty of use and care were some of the reasons for early abandonment found in these studies.

On the other hand, if designed properly, wearable technologies could bring many opportunities for sustainability. Indeed, it has been argued that with different design considerations, designers can directly influence the whole product life cycle from production processes to use practices and generation of waste [29]. Therefore, it is considered vital that the adverse impacts of wearables are tackled at the design and development stages before they materialize on a large scale $[22,30]$. However, while wearable technology designers are in the key position to influence the environmental impact, few are educated in the area of sustainability [22] and, therefore, do not pay enough attention to it. Moreover, stakeholders involved in the design of wearables can be reluctant to consider negative environmental effects because of the ongoing quest for commercial success [20] (p. 287).

To move toward a more sustainable society, we need to rethink how we design our products [31]. Therefore, this article aims to provide a vision of how sustainability aspects can be taken into account by designers of wearables. An approach that considers both production and consumption of wearables is used instead of focusing solely on the production side. We also aim to include the socio-cultural aspects of consumption. The goal is to develop design guidelines for fashionable wearable designers that address the issue of environmental sustainability throughout the product life cycle. We introduce an overview of the major considerations in the design process in order to design smart clothing that is environmentally sustainable, functional, and aesthetic, with the following research question in mind: "How should fashionable wearables be designed to better meet consumer needs and preferences in a more environmentally sustainable way?" To address this question, environmental sustainability is considered in this article in a number of models and principles. For instance, the "cradle-to-cradle" concept [32] assumes that producers approach material objects from the point of view of a life cycle and demonstrate care about the environment and human well-being by producing products that can be disassembled and integrated into new products instead of being disposed. It has appeared in opposition to the "cradle to the grave" principle, a linear, one-way model in which things are made of valuable resources, shaped into products, sold, used for a time, and eventually end their lives in a landfill [32] (p. 27). A similar nonlinear, circular approach built into an economic model is called the "circular economy", which "turns goods that are at the end of their service life into resources for others" and by doing so closes loops in industrial ecosystems and minimizes waste [33] (p. 435). The main circular economy principles are to reuse what you can, recycle what cannot be reused, repair what is broken, and remanufacture what cannot be repaired [33] (p. 435). Based on the model of one of the most recognized thinkers of the circular economy, Walter L. Stahel's several main stages in the life cycle of a product can be defined: extracting resources, manufacturing, distribution, use, and disposal. The circular economy has been acknowledged by scholars as an important element of sustainable development [34]. Therefore, these stages from the circular economy model will be used as an organizing structure for our article.

While designing absolutely sustainable wearables is not a feasible objective, reducing their environmental burden through rethinking product design is an important step toward a more sustainable society [31]. Therefore, based on the literature on wearables and sustainability, we introduce an overview of the major environmental considerations throughout the whole product life cycle in 
order to propose implications for the design of smart clothing that meets consumers' needs and preferences in a more environmentally sustainable manner.

\section{Materials and Methods}

For this article we studied recent developments and cases of wearable technologies discussed in the literature on the topic. A narrative literature review approach was chosen to perform the analysis because it is able to capture in a coherent and aggregated way various perspectives on a particular research topic [35]. The narrative literature review is a qualitative approach that differs from quantitative approaches such as integrative literature reviews or meta-analyses, which are based on rigorous procedures and aimed at achieving objectivity [35] (p. 390-391). The narrative literature review summarizes the findings of various studies with the purpose of conceptualizing or reconceptualizing them into a new or more expansive understanding of a subject [35] (p. 395). The qualitative character of a narrative literature review assumes the use of such procedures as purposive sampling for choice of literature or coding for analysis [35] (p. 397). The narrative literature review implies conceptual structuring of the topic [35] (p. 395). This approach works well for our research goal aimed at reconceptualizing existing literature on how sustainability can be met at various stages of the product life cycle and on informing fashion designers about how wearables can be designed in a more sustainable way.

This study was based on academic articles, conference articles, book chapters, and dissertations as sources of data and built using thematic analysis, a type of coding commonly utilized across social sciences [36]. The goal of the analysis was not to make an exhaustive review, but to identify in the literature on wearables and sustainability the main themes, sub-themes, and their content, which can become a base for formulating implications for designers in accordance with our research question. Thematic analysis was chosen mainly because it is a flexible and systematic method for generating themes and sub-themes from qualitative data [36]. The interdisciplinary team of four authors analyzed the themes and sub-themes related to the research question in the following ways. First, we looked at the intersection of three main themes in which the topic and the research question of the articles unfold according to the chosen definition of wearables: fashion design, information and communications technology (ICT), and sustainability. Second, we made a graph presenting the intersection of these themes, which resulted in sub-themes that included sustainability and fashion, sustainability and ICT, and sustainability and wearable technologies (Figure 1). Taking these three sub-themes as a base for the structure of the article, using Google Scholar search engine we identified corresponding streams of literature, focusing on the articles and issues relevant for designers. We picked lower level sub-themes based on Stahel's model: extracting materials, manufacturing, distribution, use, and discard. The decisions to select particular content for the sub-themes was a result of discussion between the authors. The main criterion was whether the content of a sub-theme "captures something important in relation to the overall research question" [36] (p. 82) and could also contribute to guidelines for designers of wearables. Importantly, themes and sub-themes can be picked deductively, from existing theories or concepts, or inductively, from data. We identified the main themes and sub-themes deductively, whereas their content came from an inductive, "bottom up" way [36]. Overall, the search categories were "wearable technology", "sustainability", "fashion", and "ICT." In addition, within the search results we looked for such categories as "materials", "manufacturing", "distribution", "use", and "discard." We included articles that reflected our themes, sub-themes, and could serve as a source of guidelines for designers and excluded the ones that did not reflect these themes. To finish, we gathered examples of cases from the industry, governmental organizations, NGOs, and design research to illustrate the guidelines. 


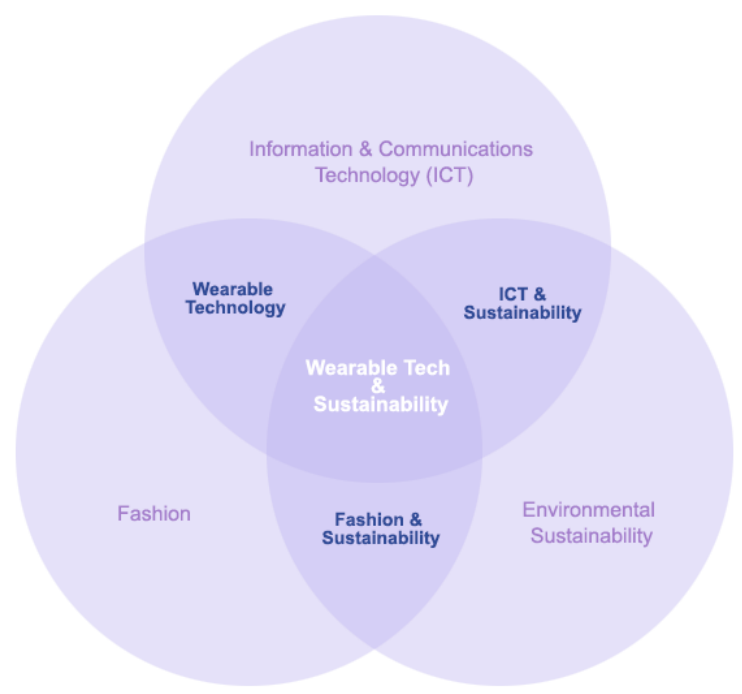

Figure 1. Key themes of analysis: Fashion, technology and sustainability.

The sample used in this research is purposive-that is, we picked articles that corresponded to our research question and the chosen conceptualization [37] (p. 416). The principle of theoretical saturation was applied to decide when to stop collecting data [37] (p. 420), which meant when each of our sub-themes corresponding to the section of analysis was covered. Qualitative research has its own criteria of validity and reliability. Rozas and Klein [35] (p. 397) mentioned that recognized assumptions must be honored, and the resulting limitations should be explicitly acknowledged. Because it is difficult to achieve replicability in qualitative research, other criteria are used to determine quality [37] (p. 390). For instance, inter-observer consistency, when the research team that includes several members agrees about what is observed, is one such criterion. Another criterion is internal validity, which means a good match between researchers' observations and theoretical ideas that they develop. The limitations of such an approach, first and foremost, are that the qualitative research in general is "too impressionistic and subjective" and relies too much on researchers' views [37] (p. 405). Narrative literature analysis, in particular, is difficult to replicate and can be driven by a dominant theoretical scheme [35]; therefore, some literature can be overlooked. Despite these limitations, one should not undervalue narrative literature review as a source of aggregated knowledge [35] (p. 390).

The article is structured as follows. First, we present an overview of the three main elements of the review: the intersection between fashion and sustainability, ICT and sustainability, and wearable technologies and sustainability. While considering the main themes, we provide some related practical examples. After that, we discuss implications: what should be taken into account by designers and developers of wearable technologies if they want to be more sustainable. The results are organized and presented in a table summarizing our findings and implications, followed by concluding remarks.

\section{Results}

\subsection{Fashion Design and Sustainability}

Wearable technologies include clothing, textiles, and accessories; therefore, issues related to sustainability of the fashion industry are relevant. The fashion industry is one of the most polluting industries in the world, producing $20 \%$ of wastewater and $10 \%$ of carbon emissions globally, with textile dying as the second largest global polluter. As an example, it takes around 2000 gallons of water to make a pair of jeans [38]. An average kilogram of textile has a carbon footprint of $15 \mathrm{~kg}$ and a 10,000-L water footprint [39]. Previous studies have shown that the decisions made in the design stage of a fashion garment "have a significant impact on the sustainability cost of a product's lifecycle, including pre-production, production, distribution, use, and end-of-life stages" [40] (p. 41). 


\subsubsection{Extracting Materials}

When analyzing problematic aspects of clothing, textile, and accessories production, scholars point out the importance of choosing and sourcing materials, the treatment of fabrics, and production methods [41]. In a summarizing article on the possibilities and challenges of fashion and sustainability, Aakko and Koskennurmi-Sivonen [41] (p. 16) mentioned that every single fiber has both virtues and problems in terms of sustainability. Therefore, it should be taken into account whether a fiber is biodegradable, whether it is made from renewable resources, or can be recycled or reused. For instance, cotton is a natural fiber but has issues with its farming, irrigation, harvest, and pesticide use [41] (p. 16). In turn, polyester is a synthetic fiber and does not have problems similar to naturally grown fibers, but even its recycled forms, produced out of plastic bottles, are toxic to the wearer and the earth [42]. Man-made cellulose fibers, such as viscose and lyocell, are made from renewable plants and are biodegradable, but they present challenges in sustainable sourcing [43] (p. 3). Reused and recycled materials (pre- and post-consumer waste) can offer a way of doing fashion in a more sustainable way. Fletcher [44] (p. 264) suggested utilizing local materials as a way of being sustainable.

Washing of textiles and clothes is a significant environmental problem since it releases "half a million tons of microfibres in the ocean every year" [38]. Therefore, choosing materials that require less laundering (such as wool), or ones that can be laundered with lower temperature and air-dried, can contribute to sustainability [41] (p. 18). Better instructions for washing and care can also help. Since the low quality of garments is one of the biggest problems for consumers, designers and manufacturers can provide information on how many washes the garment can take and still look good [45] (p. 1879).

Overall, there are knowledge bases that can help in identifying how sustainable a material is. For instance, in the US, the Council of Fashion Designers of America developed a Materials Index database that provides a description of the environmental impacts and issues related to each material, as well as alternative materials that are less harmful—for example, in the entry for wool, cloudwool is offered as an alternative [46]. As an example of a global nonprofit organization, the Better Cotton Initiative supports more sustainable development and sourcing of cotton and provides resources for its members-in particular, through the Better Cotton Standard System that sets criteria for evaluating sustainability in relation to cotton production [47]. There are standards that can be used by designers and companies, such as Global Organic Textile Standard (GOTS), aimed at assuring the overall organic status of textiles [48]. In addition, Global Fashion Agenda developed a set of toolboxes that can be used as a source for designers and companies on the road to circular fashion [49]. Among these, Circular Design Toolbox [49] offers information on choices of materials in the context of circular design.

\subsubsection{Manufacturing}

When chosen, a fabric goes through such processes as desizing, scouring, bleaching, dyeing, and printing; these processes require the use of water, energy, and chemicals that are sometimes hazardous. The designers are not necessarily responsible for these processes, which are a part of production, but they can make themselves aware of the effects of these processes and consult the guidelines on the least harmful techniques [41] (p. 17). In a similar vein, even if a designer does not have control over it, transparency of the supply chain is another issue that should be taken into account [41] (p. 17). For more sustainable patternmaking, zero-waste or minimal waste techniques can be used [50]. The use of eco-labels can signal consumers about the safety and sustainability of a garment [41] (p. 19). An example of eco-labels is the EU Ecolabel Clothing and Textiles program [51]. To help assess the overall environmental impact of a company on the environment, designers can use the ISO 1400 standard [52].

Fast fashion is a common business model of clothing production in contemporary society; it epitomizes unsustainability [44] (p. 259). Fast fashion has caused "an unprecedented decrease in the production time, price, and lifespan of fashion items resulting in a trend of over-consumption and the desire to pay the lowest possible price for the most products" [40] (p. 41). Additionally, this model has led to the exploitation of workers [40]. Fast fashion is based on extremely fast cycles of fashion and caters to the fickle desires of consumers. Accordingly, low quality, short-term use, and frequent 
clothing replacement, leading to increasing textile waste, cause an environmental burden [45] (p. 1878). Slow fashion is an alternative business model and incorporates a different worldview that "represents the vision of sustainability in the fashion sector" [44] (p. 262). It implements the use of local resources and markets, along with small-scale production, and is based on traditional craft techniques [44] (p. 264). Slow fashion questions the obsession of fast fashion with image and newness and places emphasis on making over watching and seeming. The radical alternative that slow fashion offers designers over the high-volume, standardized, and cheap fast fashion is producing and selling fewer items for higher price [44] (p. 264). On a practical level, the Garment Collection Toolbox-an instrument developed by Global Fashion Agenda-helps designers to build a business model that is closer to slow fashion [49].

\subsubsection{Distribution}

Distribution is part of company's business model. In the fashion industry, transportation and logistics are an important part of the business, ensuring that customers can buy the product when and where they want it. Meanwhile, companies strive to reduce the cost of bringing products to the consumer. Scholars have proposed a "sustainable fashion supply chain" that should include green distribution and green retailing [52] (p. 6236). The main criterion here is reduction of emissions resulting from the fact that supply chains can include actors that are a long distance from one another [52] (p. 6239). Sourcing locally may be desirable for a more sustainable distribution practice [52] (p. 6239). As for selling the product, marketing and branding should include such concepts as sustainability and eco-consumption [52] (p. 6239), [44] (p. 262). The importance of corporate social responsibility has grown in fashion [53]. To promote the green agenda, a brand can increase the visibility of sustainable products, increase the transparency of a product chain through labeling schemes, and communicate sustainable/ethical concerns in its advertising campaigns, among other measures [52]. Offering recycling services as well as recyclable products in a store can contribute to consumers' awareness of sustainability [52] (p. 6239). As an example, in addition to other toolboxes that allow designers to build and assess the whole life cycle of product, Global Fashion Agenda offers a Resale Toolbox that is aimed at designers and companies who would like to explore resale opportunities as a part of their distribution strategies [49].

\subsubsection{Use and Consumption}

Scholars of fashion design and sustainability systematically argue that it is not only production that is important, but a drastic change in consumption patterns is needed as well [45,54]. According to Global Fashion Agenda [39], many of the 9.5 million tons of textiles that EU citizens purchase each year are discarded, long before they are worn out. Moreover, in the EU, 30\% of wardrobes' contents have not been used for at least a year. Designers have the ability to contribute to strengthening the connection between a consumer and a product through an empathic design approach $[45,54]$. If a deeper attachment between them is developed, then product replacement is postponed [54] (p. 167). Research shows that memories, which can be rooted in personal history or meaningful events, and enjoyment, which is linked to emotional, tactile, olfactory, or kinetic experience, can positively contribute to the degree of attachment [54] (p. 169,170). Scholars have concluded that a discussion about consumers' deeper inner needs, values, and meanings can guide designers toward sustainability [54] (p. 176). Among the ways of deepening this attachment are personalization and do-it-yourself practices, modular structures, as well as customization and design services with the use of digital technologies, co-design and co-authorship [54] (p. 177) [45,55]. The element of surprise, embedded in design objects, can be another tool for stronger engagement of a consumer [55]. Instead of "programmed obsolescence", the method of surprise implements "programmed alteration"-for instance, using thermo and ultra-violet (UV) reactive dyes that change the color of a material in the process of use [55] (p. 523). Moreover, a wardrobe audit is the method based on a collection of personal reflections and insights into wearing practices that allows designers to deepen their understanding of the person-product attachment [56] (cited in [57] p. 228). 
This approach is further developed in the concept of slow consumption, which encourages buying quality over quantity, and thus entails a longer product life span from manufacturing to discarding [58]. Slow consumption offers a holistic view that takes into account both the production and use stages [58].

\subsubsection{Disposal: Recycling, Mending and Repair Activism}

Since recycling is often criticized as resource-intensive, in particular with energy use, other forms of prolonging the life cycle of clothes are considered more sustainable. Repairing and mending contribute to the support of garment longevity $[59,60]$. Scholars have discussed the revival of repair and mending in the industrial context and at home [59]. They emphasized new meanings of repair and mending. Historically, repaired clothing was a signifier of financial hardship, and this meaning persists [59]. However, such new meanings as community engagement and sustainability sensibilities [60] are the drivers for consumers' participation in repair practices today. For designers, this opens the possibility of attaching repair to the business models of their companies, to inspire consumers to mend. Repair activists, however, emphasized that these practices are on the periphery of the fashion system and must be brought to its center [61] (p. 263). Repair activism is considered a political and ecological action in affluent societies, a resistance to "throwaway society" [62]. Repair activism as well as repair cafes and restart parties have become parts of a politicized lifestyle movement to foster socio-political changes in the transition toward a more sustainable future [60]. Since lack of knowledge often prevents repair [62], designers can contribute their knowledge and skills to such initiatives. Another alternative discussed is found in the sharing economy, including rental and leasing services and the clothes-as-a-service business model [63]. Designers can utilize the Textile Recycling Toolbox to assess opportunities to contribute to a circular fashion system [49].

Thus, we have shed light on how sustainability is considered in scholarship on fashion design research. In the next section, we proceed to the analysis of literature on sustainability in relation to information and communication technology.

\subsection{ICT and Sustainability}

Wearable technologies include technological components; therefore, issues related to sustainability and ICT are also relevant. Mass production and consumption of high-tech products have an increasingly negative environmental impact. The overall energy consumption and greenhouse gas emissions of the ICT sector are expected to double its contribution on a global level from $1.6 \%$ in 2007 to 3-3.6\% by 2020 . Based on this trajectory, by 2040 it could account for more than half of the current contribution of the whole transportation sector [64]. Assessing the overall environmental effect of ICT is a very complex and multifaceted problem. One undisputed fact is that the ICT industry has a growing footprint in the environment. In the next sections, we will briefly outline some major effects of resource extraction, manufacturing, usage, and disposal, and some of the steps that have been taken by researchers and practitioners toward improving the ICT sector and environmental sustainability.

\subsubsection{Material Extraction}

Even though the amount of physical mass needed to represent one bit of information is decreasing continuously [65], the ICT industry is increasingly dependent on a variety of exotic and rare metals [30]. An average ICT device today is comprised of a variety of materials such as metals (e.g., iron, aluminum, copper, gold), polymers, glass, and rare earth elements (REEs), including dysprosium and neodymium [65]. Over the last decades ICT devices have become progressively complex in regard to material composition. Indicative of this trend is the fact that an average microprocessor in the 1980s was comprised of 12 elements while in 2011 this number rose to 57-60, claiming up to half of the elements on the periodic table [66]. The benefits of material diversity and the utilization of exotic metals are faster computers, more energy efficient devices, higher screen resolutions, and better performing ICT products [30,67]. However, escalating demands on the finite supply of scarce metals is steadily leading to an impending depletion of mineral deposits $[30,68,69]$. In addition, material 
composition complexity makes disassembly and recycling of materials difficult and not economically feasible. Therefore, producers are advised to use eco-design guidelines, including the incorporation of non-composite, non-blended materials (i.e., avoid alloys, choose biodegradable plastics) wherever possible $[70,71]$. Such conscious selection of materials results in less environmental impact.

Resource depletion would not only disrupt production of electronics and high-tech products but also affect a wide spectrum of industries, such as aerospace, automotive, and even green energy. One of those elements, neodymium (Nd), for example, is used to create permanent magnets that are utilized in wind turbines and electric cars. Another example is indium (In), which is used in thin-film solar cells. However, both of these elements are also applied in ICT products such as flat screens, mobile phones, and speakers. The unique physical and chemical properties of these elements make them crucial and non-substitutable for a variety of sectors, which raises the question of whether their increased demand can be satisfied. Recent studies have shown that over the next two or three decades we could face shortages of several minerals if current mining practices do not adapt to the increased demand $[67,72,73]$. Mining can have a substantial environmental impact, since it requires extensive use of separation agents, energy, and water, while it also releases large amounts of toxic waste, contaminating the air, soil, and water in the region of the mining site [69]. Currently, no single country is able to produce all the materials that can be found in a typical ICT product, though substantial mineral deposits of specific elements are concentrated in only a handful of geographic areas (e.g., REEs in China, copper in Chile) [67].

Designers can influence the environmental impact of the products they develop by making conscious choices about which materials they use. Lists that have been created to assess the sustainability of raw materials can be utilized to aid decisions of material selection during the design process [74]. The European Union, for example, publishes an annual report on the criticality assessment of raw materials with a risk of supply interruption alongside information about substitution and recycling [75]. It is increasingly common for vendors to offer their products as remanufactured or refurbished items, which gives designers a more sustainable, closed-loop option [76,77]. There are also new materials and designs for circuit boards that can be disassembled instead of thrown away [78]; we expect to see more development in this area and encourage designers to support these efforts.

\subsubsection{Manufacturing}

In order to assess the environmental impact of the manufacturing of electronic components and the final assembly of ICT products, the energy consumption during these processes must be considered. The term "grey energy" has been used to refer to the indirect and cumulative energy consumption throughout the life cycle of a product $[79,80]$. As ICT devices become smaller and more energy efficient, the relative importance of energy consumption during production increases [80]. However, energy consumption is only one factor contributing to the industries' environmental footprint. A more comprehensive picture can be acquired by considering raw material consumption, the output of waste, and the emission of substances into the air, water, and soil [81]. Large amounts of toxic materials are required for the production of ICT components such as semiconductors, printed wiring boards, and cathode ray tubes, for example [82]. Legislation and directives have been formulated to prevent the use of toxic substances (e.g., lead, cadmium, and mercury) in ICT products, such as those outlined in the European Union Restriction of Hazardous Substances Directive (RoHS) [83]. Apart from legislation, industry standards for sustainability have also been developed (e.g., EPEAT) alongside energy labels (e.g., US EPA ENERGY STAR [84]), aiming to create consumer awareness about product compliance with best practices. The ICT industry is also monitored by environmental organizations such as Greenpeace in regard to its environmental impact [85]. Since 2006, Greenpeace has published a report-the Guide to Greener Electronics-in which they rank the largest ICT companies on the topics of energy efficiency, resource consumption, and use of chemicals [86]. Designers can use these lists and directives both as guidelines for product development and as a tool to make informed decisions about component vendors. 


\subsubsection{Distribution}

Energy consumption, greenhouse emissions, and pollution created during the transportation and distribution of ICT products contribute to the industry's environmental impact. Dematerialization has minimized the need for transportation of some products, such as software packages-like a CD-ROM in a box - that do not need to be purchased in physical form anymore and can instead be downloaded online. However, a multitude of physical ICT devices still need to be transported and made available to the consumer through traditional distribution channels. For those products, designers should consider product and packaging weight and volume, if possible employing folding, nesting, or disassembly to allow product distribution in a compact state [69]. There are alternatives for distribution, such as product-service systems (PSSs), a distribution model in which the consumer pays a fee for using a product but does not own the physical artifact. This minimizes the total number of units produced, yet consumer experience is supported-however, the consumer takes possession of the products only when needed [87]. In turn, this leads to less waste from overproduction, simplifies the distribution of products, and reduces inventory demands. However, a PSS can be complex, thus requiring deliberate and persistent focus on sustainability at key checkpoints across the supply chain [88].

\subsubsection{Use and Energy Consumption}

Energy labels—such as ENERGY STAR from the US government [89] and the EU energy label EPEAT [90]-help to mark products that consume less energy during their use. However, since modern ICT devices are interconnected, a considerable amount of energy is consumed not by the device itself but by remote data centers and backbone infrastructure. Data centers accounted for $61 \%$ of the total ICT industry environmental footprint in 2010, and this is expected to reach $79 \%$ in 2020 [64]. This illustrates that online actions have a hidden cost that is not easily apparent to the end user. A simple search on Google, for example, has the energy equivalence of turning on a 60-watt light bulb for $17 \mathrm{~s}$ [91]. The energy consumption of the video streaming service YouTube for the year 2016 has been estimated to be $19.6 \mathrm{TWh}$, leading to greenhouse emissions comparable to the annual emissions of an urban area such as Glasgow, Frankfurt, or Quito [92]. Information is not an ethereal entity that is free of any materiality, and this example shows that storing, transmitting, retrieving, or processing it has environmental consequences. This also has implications for software developers and designers, since the energy profile of ICT devices or the software applications they develop has to account for both local and remote energy use if they utilize remote data communication or processing. Designers must consider carefully if using cloud services is a better alternative regarding energy efficiency, rather than adding capabilities to the device itself. In addition to assessing product performance with respect to energy efficiency (both hardware and software), designers should consider energy consumption when a device is idle.

While designers have traditionally focused on developing products that are attractive and accepted by consumers, there is an increasing focus on designing objects that can be appropriated into the unique lives of consumers, including customization and supporting end user repairs. The Fairphone is an example of a consumer electronics product that integrates repair as part of the design, enabling the user to add, remove, and repair the main components of the mobile phone [93]. Recently, the "Right to Repair" acts in the US and the EU have supported consumers' right to repair and maintain the products they buy, especially electronics [94]. While it can be more expensive for producers to build products that support end user maintenance and personalization, the benefits support a sustainable design agenda.

\subsubsection{Disposal}

Technological innovations and decreased prices have contributed to a rapid and widespread adoption of short-lived ICT products by an ever-growing global population, creating the fastest growing waste stream worldwide [95]. E-waste treatment is not only challenging in regard to material extraction, but is an environmental concern of its own. ICT devices contain not only a variety of valuable 
materials (e.g., copper, gold, silver, and REEs) but also a number of hazardous heavy metals (e.g., lead, cadmium) and halogenated organic compounds that can harm human health and create ecological risks $[69,81,96]$. These hazardous materials can be released into the environment while leaching from landfills, during incineration if mixed into municipal waste streams, or during recycling [95]. Formal recycling procedures of ICT products in regulated facilities can minimize toxic emissions and health risks. However, a significant bulk of e-waste is treated in informal backyard facilities in the developing world, such as China, India, and Nigeria [96]. Practices in these informal recycling facilities include the burning of insulated cables to extract copper-which can release dioxins, furans, and other toxic chemicals-or the use of cyanide to recover gold from printed circuit boards, in the process contaminating water, air, and soil [97]. Even though informal recycling has led to severe health and environmental problems in the developing world [69,98-100], efforts to end this practice through legislation and trade restrictions have been unsuccessful due to difficulties in enforcement [96].

One of the proposed concepts that can improve the recyclability of ICT products is Design for Disassembly (DfD) [101]. In order to facilitate DfD, designers must employ techniques that allow for the easy separation of materials, minimizing the environmental impact, and therefore facilitating reuse, remanufacture, recycling, or even maintenance of products [102]. A good example of this concept is provided by the ReUse project [103], which led to the development of a printed circuit board (PCB) whose components could be separated by simple immersion into hot water, thus improving its sustainability.

This section reviewed studies on the link between ICT and sustainability. The issues discussed above, related to both sustainability and industries, are also relevant to wearables. The following section analyzes scholarship on wearable technologies that combine both clothing and accessories, on the one hand, and a technological element, on the other hand.

\subsection{Wearable Technologies and Sustainability}

Even though the field of wearable technologies has increasingly recognized concerns related to sustainability, it has not yet adopted sustainability as an industry driver [29]. In addition to the environmental issues related to the fashion and ICT industries discussed in the previous sections, wearable technologies create novel, unique challenges that should be addressed. Yet there are many opportunities that can be realized if wearables are designed, produced, used, and disposed of in a more sustainable way [1].

\subsubsection{Selection of Materials}

The sustainability of a given item of wearable technology depends on the sustainability of its various components [104]. Accordingly, designers must take into account both the sustainability of the article of clothing or bodily accessory - including fabric, fasteners, buttons, and yarn - as well as the sustainability of its integrated electronic system — such as electronic components, sensors, batteries, or displays. In addition, material choices have a direct influence on the sustainability of the whole product life cycle, including sourcing and distribution, care and maintenance practices, product durability, functionality, aesthetics and comfort, as well as on the end-of-life treatment in terms of reusability and recyclability. A study by van der Velden et al. [22] demonstrated the importance of material selection in environmentally conscious product design. They used the method of life cycle assessment (LCA) already at the prototyping stage to analyze and compare different materials and their respective eco-costs and found that the same desired smart capabilities and design results were achieved by using alternative materials with less environmental impact. Their research shows that designers working with smart materials should consider what alternative options there are that do not interfere with the targeted user experiences [22]. Also, sourcing recycled materials and upcycled components instead of new ones is an important design strategy, especially in small-scale production and in research and development. Designers should be encouraged to harvest and utilize electronic components from retired consumer electronics, including motors, lights, and actuators, as well as structural and mechanical parts such as buttons and hinges [105]. 
True sustainable production requires that a product is designed in a way that the valuable resources inside it are not lost at the end of the product's life cycle. Closed-loop design, also referred to as cradle-to-cradle-based on the cradle-to-cradle principle discussed in the beginning of this article-is an alternative design approach that aims to eliminate or reconceptualize the concept of waste [20]. In this approach, the materials used should be either biodegradable, so that they can be safely returned to the environment, or reusable, so that they can be easily reused, remanufactured, or recycled into new materials and products [20] (p. 285). Prahl's research, which investigated the closed-loop design opportunities for wearable sensors, recommends using natural and synthetic nonwoven materials-which are suitable for reuse and recycling-along with transient electronics, which are dissolvable at the end of their life [20]. The use of advanced biological responsive materials, such as natto cells to achieve both functionality and biodegradability, has also been researched [106]. Other examples of biodegradable electronic concepts include biobatteries made of paper [107] and electronic ink made from cuttlefish ink $[20,108]$. Overall, the sustainability of materials such as smart textiles requires a system-thinking approach and depends on the sustainability of its components [109].

\subsubsection{Manufacturing}

The cradle-to-cradle model extends to manufacturing, as it is important to ensure that when a product reaches the end of its life, the energy used to manufacture it is preserved as much as possible. While this is relevant for the disposal phase, there are choices in the manufacturing techniques and design of the parts to enable ease of assembly as well as disassembly [110]. The level of integration of the components for wearables directly impacts this, and when electronic components are involved, they can be either embedded within the fibers (jacquard) or removable parts. A design approach that aims for a low degree of integration will be beneficial not only for reuse and recycling, but also for washing, cleaning, and updating rapidly changing technology [111]. An example of a low level of integration includes a shirt where the smart object is built inside a button or incorporated into pockets. However, as seamless integration has become the ultimate goal of smart textile designers, permanent and invisible integration methods-such as knitted, woven, printed, embroidered, laminated, and welded technologies-have prevailed lately on the innovation agenda [20,112]. In addition to levels of integration, alternative methods of disassembly should be considered. For instance, active disassembly, triggered degradation, or end-of-life unzipping of electronics are methods that enable recovery levels of over $90 \%$ of the original structure [20] (p. 293).

There are also business models that move parts of the design, manufacturing, and assembly closer to the consumer, such as those offered by IKEA. Involving the consumer in the process also provides an opportunity for them to feel more connected to the product. In terms of wearable technologies, various toolkits are emerging that help both the designer and end user to develop functional wearable prototypes. LilyPad, which is based on the Arduino platform, is distributed through SparkFun and other channels and enables the end user to design and build wearables [113]. Adafruit developed a line of similar wearable electronics components called FLORA. They also provide many how-to guides and tutorials to educate designers on how to make their own wearables [114]. Developing wearables is challenging, and the toolkit approach saves time and resources to enable wearable prototype development. Another example, the FlexAbility toolkit, assists designers in developing wearable technologies for people with physical disabilities [115]. With the rise of 3D printing, direct digital manufacturing - a process by which the consumer can print the product or parts as needed-radically changes existing manufacturing models while at the same time challenging businesses to develop successful business models [116].

\subsubsection{Distribution}

Distribution of products to the market and consumers results in significant environmental impacts. Yet designers can plan the distribution channels to minimize this intangible element. Increasingly, the open source hardware movement results in designers or end users being able to follow instructions 
to fabricate the devices without the need for shipping [117]. Moreover, the concept of open source product design was found to have an influence on the use and end-of-life phases, namely maintainability, repairability, upgradability, reusability, and recyclability [118] (p. 57).

\subsubsection{Use and Consumption}

Laundry and maintenance create challenges for fabrics and other materials with an electronic component. However, when it comes to use practices, smart textiles are often introduced as a potential development that could render the textile industry more sustainable, since they are expected to enhance textile durability as well as to shift the way we have traditionally taken care of our clothes. One prominent stream of innovation in this regard is self-functioning textiles. Self-functioning abilities-such as a photocatalytic self-cleaning coating which removes stains, bacteria, and odor by degrading dirt particles and organic substances [119], or a textile finish like Nano-Tex [104,120], which eliminates wrinkles-can help to reduce maintenance-related resource consumption including human effort, detergents, water, and energy [119]. Furthermore, self-healing textiles-conventionally developed by using a chemical coating finish of microcapsules, hydrogels, or other polymeric matrices-can repair torn surfaces with automatic self-repairing functions and thus extend the product life cycle [119]. While designers of smart clothes are encouraged to consider different and novel ways of reducing the environmental impact generated during the use phase, they should also consider how users can be educated about the correct maintenance, care, and repair practices, as it is important that they master these basic skills in order for the intended sustainability benefits to be fully realized.

Energy consumption is an issue through the whole life cycle of wearable technologies, from the material selection, garment production, and distribution phases to the use phase. While this energy consumption is expected to decrease due to changing care and maintenance practices, integrating electronic components into regular clothes and accessories is likely to increase it. So far, most of the wearables on the market today are powered by batteries that must be replaced and disposed of or charged frequently. In this context, the use of alternative, more sustainable energy harvesting methods has been researched. For instance, photovoltaic (PV) cells, which convert the sun's rays into electricity, have developed to the point where they are physically flexible enough to be integrated into garments $[16,29,121]$. Ideally, solar energy would be used to power not only the apparel itself, but also other devices, such as mobile phones [111] (p. 326). In addition, thermoelectric generators that produce electricity from a temperature gradient represent an alternative power source to batteries [122]. However, due to the high power consumption of most wearables, and the limited energy that can be captured by sunlight or body heat, creating truly energy-autonomous applications is challenging. One promising way to ensure an immediate, continuous, and sustainable power supply for wearable electronics is to harvest biomechanical energy [123]. By a material- and structure-optimized triboelectric nanogenerator (TENG), human motion can be converted into electricity [123]. Such technologies are currently under development and indicate the rapidly expanding possibilities for addressing issues of sustainable energy consumption in wearables.

Purchasing a wearable product should not increase the need for-and thus consumption of-other technological gadgets, such as tablets or laptops [124]. Therefore, the technological independence or multi-platform usage of wearables should be assured. Furthermore, in order to avoid technological obsolescence, smart garment applications should be in constant development so that the technology is always up-to-date and compatible with the newest software, ensuring continued ease of use within the digital ecosystems of the user [124] (p. 166).

Another issue that should be considered regarding sustainability is whether wearables meet users' needs. Failing to meet user needs can result in early abandonment and disposal of wearables. There are many studies that have examined the main factors supporting sustained use of different types of wearables, and some of the frequently mentioned reasons for early abandonment include unattractive design, useless functions, and difficulty of use and care [26-28]. User needs can be divided into utilitarian and hedonic needs, of which the latter is considered to be more crucial—in our modern 
world clothing is more likely to be worn because of social conventions rather than because of its functionality $[9,27]$. It has been claimed that functional high-performing devices may be abandoned if aesthetics are not considered [9]. This stems from our tendency to communicate to others about ourselves through the aesthetic and expressive elements of our clothing. Thus, people do not wear devices that do not address their aspirational and style needs [9]. Moreover, it has been found that visual attractiveness is not only about looks, but can also have an influence on usability ratings [125]. When it comes to functionality, it is noted that smart clothing should not "interfere with the wearers' everyday life" or require too much effort to use or maintain [26]. Wearable technologies must be comfortable to wear and flexible in order to adapt to the movements of the body [126]. Further, having multiple functions and use purposes instead of one was preferred among end users [127]. In addition, wearables can have functions that help to optimize the eco-efficiency of numerous other daily activities [1] (p. 214). As a part of smart home vision, wearables can offer an opportunity to avoid unnecessary energy losses in many areas of life, such as heating, lighting, and mobility [128]. In that sense, wearables can be designed to include functions that can persuade their users to commit to a more sustainable behavior [1].

In order to prolong their use, wearable technologies should be designed to enable the end users to customize and even hack the product to better fit into their lives in order to effectively meet their needs (cf. [129]). Indeed, designers of wearables are also encouraged to consider how to allow users to change the different features of devices according to their own needs, preferences, and personal style, as it has been found that users' requirements for wearables and aesthetical aspects change with different contexts of use $[10,11,130]$. Furthermore, this creative freedom to modify wearables can help build the meaningful connection between the user and the device through which the product's life span can be extended $[29,104,124]$.

In this context, an outfit-centered design approach—which argues that wearable devices should be designed in a way that they fit with users' clothing and jewelry fashion-has been supported (i.e., $[10,17])$. In short, a long-lasting and aesthetically pleasing wearable device should be classical in style, but at the same time easily transformable according to different trends. Such transformability can be achieved, for example, through color- and pattern-changing textiles-enabled by different display technologies-or silhouette-, size-, fit-, and design-changing smart clothes that can be produced using motors or mechanical controls, shape-memory alloys, or inflatable materials [131].

On-body placement and engagement with the product can influence a product's longevity [17]. Exactly what determines socially acceptable placement for wearable technology differs with respect to gender and different cultures [9] (p. 4162), but most studies indicate that the wrist is currently the most suitable body location for placing a wearable computer since it is less intrusive and less of a social anomaly $[27,127,132]$. A study by Smelik et al., which explored the integration of photovoltaic (PV) cells into fashion from the users' perspectives [2], concluded that wearables should be tailored to the body if their aim is to be socially acceptable and become sustainably integrated into users' everyday lives.

Overall, "crowdfunding"-referred to as the newest dimension of user-involved design-is argued to be an efficient way to quickly determine which design initiatives are worth producing and distributing, based on the amount of pledges the product receives [104] (p. 410).

\subsubsection{Disposal}

The amount of e-waste, which is already considered a global sustainability problem, is likely to increase when wearables reach their end of life and give rise to new disposal and recycling issues [1]. Regular garments are difficult and costly to recycle, mainly because they are made of many different substances-from different fibers to non-textile-based components such as zip fasteners and buttons [104]. Adding electronic components to garments will only make the recycling process even more complicated. Disassembling the different components, namely electronic systems, energy supplies, and interconnecting wires or fiber-optic cables, may be difficult or even impossible as the development of wearables heads 
toward seamless and permanent integration. As a result, numerous small e-waste items that contain problematic and toxic substances — such as heavy metals and halogenated organic compounds—can end up in normal household waste or find their way into recycling processes where they act as contaminants [133]. Through competitions and public recognition, governmental initiatives have encouraged the development of responsible recycling and disposal for companies involved in production [84], yet there is a patchwork of legislation for e-waste that is confusing for both producers and consumers [134]. In the research literature there are attempts to develop a methodology for assessing the end of life (EOL) of household appliances and electronics with an aim toward reuse and recycling [135].

To tackle the issue of e-waste, new solutions for products' reuse, remanufacture and recycling have been implemented, including material innovations and Design for Disassembly like those discussed earlier. Ideally, designers should strive toward designing products that do not need to be disposed of in their entirety (modularity). Additionally, by assisting the consumer in properly disposing of or recycling parts of the product, the environmental impact of components like dangerous chemicals and batteries can be minimized. In this respect, product-service systems (PSSs) can be especially beneficial, as they help to close the loop and encourage the consumer to return pieces in exchange for another, thus increasing rates of recycling and ensuring a reduction in disposal [87]. Deposit-refund systems that have helped the beverage industry in reducing waste plastics have also been used to incentivize consumers to properly dispose of electronics. Producers of wearables might consider ways to encourage their proper disposal or provide "trade-in" programs.

\section{Discussion: Implications for Design and Development of Wearable Technologies and Sustainability}

In this paper, we have analyzed literature across disciplines and fields related to fashion design, ICT, and wearable technologies to identify the main themes related to wearables and sustainability. In what follows, we propose to synthesize the main lessons learned from this literature survey by highlighting design concepts and strategies that should be taken into account to address and positively impact the environmental sustainability of wearable technologies. To facilitate this, we also provide implications for the design of wearables to encourage designers to look carefully and take account of their decisions in the design process and, ultimately, to make these decisions in ways that promote sustainability goals. Höök and Lowgren [136] position implications for design as "intermediate-level knowledge", which bridges theory with instances of design, recognizing that designers and practitioners should consider the unique circumstances of their project and adapt accordingly. We gather these implications through a review of the literature and, where possible, we connect concepts from the literature with concrete examples of wearable technologies to provide more actionable insights for designers. Combining concepts with concrete examples improves the quality of implications for design, thus encouraging validity, generalizability, originality, as well as generativity, inspirability, and actionability as proposed by Sas and colleagues [137]. In addition to the implications summarized, we encourage the reader to look more closely at the examples here and throughout this paper, as many of the referenced works share details of their process and contextual concerns under which the projects were developed. In many cases, these additional detailed accounts can be helpful in qualifying the claims and situating the findings beyond our summarized account [138].

To give structure to the types of implications provided, we take inspiration from the life cycle model suggested by Stahel [33], discussed at the beginning of the article, and indicate where in the product life cycle the implications seem to contribute most clearly. Firstly, we develop a summary of design implications for the five phases: extracting materials, manufacturing, distribution, use, and disposal. Secondly, we construct a table (Table 1) that summarizes these implications and suggests examples from the perspective of fashion design, ICT, as well as wearable technologies. The inclusion of fashion design and ICT in addition to wearable technologies is done to provide inspiration to designers of wearables, but in many cases the implications for design can be applied across the sectors. 
Table 1. Overview of themes linking sustainability to fashion design, ICT, and wearable technologies.

\begin{tabular}{|c|c|c|c|c|}
\hline \multirow{4}{*}{ 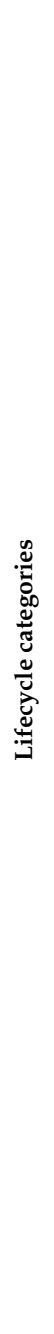 } & & Fashion Design & ICT & Wearable Technologies \\
\hline & & $\begin{array}{l}\text { - Source fibers that are biodegradable, made from } \\
\text { renewable resources, organically grown, non-toxic, } \\
\text { recycled or reused [41]. } \\
\text { - } \quad \text { Use local resources whenever possible [44]. } \\
\text { - } \quad \text { Choose materials that require less laundering [41]. } \\
\text { - } \quad \text { Consult materials from transparent supply chains [41]. } \\
\text { impact of textiles [46]. } \\
\text { - Use materials with eco-labels and certification. There are } \\
\text { many eco-labels-choose the one that suits your vision, for } \\
\text { instance, Better Cotton Initiative [47], or EU Ecolabel for } \\
\text { clothing and textiles [51]. ISO 1400 is the standard that } \\
\text { helps companies to evaluate their environmental } \\
\text { impact [52]. } \\
\text { Apply for GOTS certification to ensure organic status of } \\
\text { textiles [48]. }\end{array}$ & $\begin{array}{l}\text { - Consult databases that summarize the environmental } \\
\text { impact of materials and provide alternatives (e.g., [75]). } \\
\text { - Source materials from vendors who make conscious efforts } \\
\text { toward sustainable practices or demand this information } \\
\text { from their suppliers (e.g., [139,140]). } \\
\text { - Consider remanufacturing models for sourcing } \\
\text { materials [77]. } \\
\text { - Consider consulting with a sustainability advisory firm for } \\
\text { sourcing of materials. (e.g., [141]). } \\
\text { - Avoid alloys that are difficult to separate at the end of life of } \\
\text { a product [70]. } \\
\text { Avoid dangerous plastics and consider safer, biodegradable } \\
\text { alternatives like PLA, PCL, etc. [71]. } \\
\text { - Consider a closed-loop supply chain [76]. } \\
\text { Consider new materials for circuits that can be } \\
\text { disassembled, e.g., ReUse project [78]. }\end{array}$ & $\begin{array}{l}\text { - Analyze and compare different material options and their } \\
\text { respective eco-costs (e.g., w/method of life cycle } \\
\text { assessment) [22]. } \\
\text { - Source recycled materials and upcycled components instead of } \\
\text { using new ones [105]. } \\
\text { Consider recyclability and biodegradability of materials used in } \\
\text { order to avoid waste creation and loss of valuable resources at } \\
\text { the end-of-life stage (closed-loop design) [20]. Consider using } \\
\text { advanced biological materials that provide functionalities but } \\
\text { are biodegradable. bioLogic used natto cells for shape-changing } \\
\text { clothing for temperature management [106]. }\end{array}$ \\
\hline & :D & $\begin{array}{l}\text { - Pay attention to the treatment of fabrics; use water, energy, } \\
\text { and chemicals wisely [41]. } \\
\text { - Consider using natural dyes less harmful for the } \\
\text { environment [41]. } \\
\text { - Use zero-waste or minimal waste patternmaking } \\
\text { techniques [50]. } \\
\text { - Choose slow fashion business models vs. fast fashion [44]. } \\
\text { - Use local labor resources and traditional craft } \\
\text { techniques [44]. } \\
\text { - Consider using Garment Collection Toolbox to assess the } \\
\text { whole life cycle of a garment from the point of view of } \\
\text { sustainability [49]. }\end{array}$ & $\begin{array}{l}\text { - Source components that are certified as less harmful, for } \\
\text { instance, by EPEAT global ecolabel for IT, or ENERGY STAR } \\
\text { certification and RoHS standard for restriction of hazardous } \\
\text { substances [83,142]. } \\
\text { Use existing production platforms that benefit from scale. } \\
\text { Instead of buying production equipment, for example, } \\
\text { Protolabs has the ability to produce small runs of products } \\
\text { via injection molding and CNC milling [143]. } \\
\text { Optimize the design to use less energy, e.g., by designing } \\
\text { more efficient cooling [144]. }\end{array}$ & $\begin{array}{l}\text { - Consider the required degree of integration between } \\
\text { textile/accessory body and electronics [111]. } \\
\text { - Think about the product assembly and how the end user can be } \\
\text { meaningfully involved in the process, e.g., SparkFun [113]. } \\
\text { - Consider how to enable the product disassembly to achieve } \\
\text { recyclability [110], for instance, through a modular } \\
\text { design approach. } \\
\text { - Use toolkits that focus on sustainable development (e.g., [115]). } \\
\text { - Utilize new on-demand manufacturing models when possible, } \\
\text { e.g., 3D printing [116]. } \\
\text { - Consider production partners who are physically close to the } \\
\text { markets served, such as 3D Hubs for printing parts on demand. } \\
\text { Custom spinning machines from Studio HILO enable yarn } \\
\text { development for small and medium-sized enterprises [145]. }\end{array}$ \\
\hline & 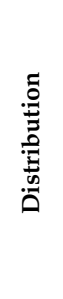 & $\begin{array}{l}\text { - } \quad \text { Reduce emissions by avoiding long distance } \\
\text { transportation [52] (p. 6239). } \\
\text { - Source locally [52] (p. 6239). } \\
\text { - } \quad \text { Use green marketing and branding [52,53]. } \\
\text { - Increase the visibility of sustainable products, } \\
\text { and communicate sustainable/ethical concerns in } \\
\text { advertising campaigns [52]. } \\
\text { - Offer recycling services in a store [52]. } \\
\text { - Use Resale Toolbox to explore resale opportunities [49]. }\end{array}$ & $\begin{array}{l}\text { - Follow the principle of dematerialization in distribution of } \\
\text { ICT products [146] (p. 4). } \\
\text { - Consider product and packaging weight and volume, } \\
\text { employing folding, nesting, or disassembly to enhance a } \\
\text { compact state [70]. } \\
\text { - Consider alternative distribution models such as } \\
\text { product-service systems (PSSs) to reduce the number of } \\
\text { units produced and simplify distribution [87]. }\end{array}$ & $\begin{array}{l}\text { - Consider "open source design" [117] hardware and business } \\
\text { models that involve shared responsibility for design and } \\
\text { development for some aspects of the system. In many cases, } \\
\text { the consumer completes the product, thus reducing distribution } \\
\text { needs. Various examples are emerging including cars, } \\
\text { microcontrollers, BeagleBone, etc. [118]. Adafruit's FLORA } \\
\text { platform can be used for wearables [114]. } \\
\text { - Use direct digital manufacturing that can reduce burden of } \\
\text { shipping [116]. }\end{array}$ \\
\hline
\end{tabular}


Table 1. Cont

\begin{tabular}{|c|c|c|c|c|}
\hline & & Fashion Design & ICT & Wearable Technologies \\
\hline 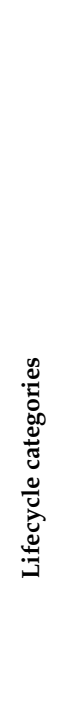 & $\stackrel{5}{\infty}$ & $\begin{array}{l}\text { - Strengthen the connection between product and user } \\
\text { with an empathic design approach [45,54]. } \\
\text { - Consider the possibility of personalization and DIY } \\
\text { practices-modular structures, customization, design } \\
\text { services [54] (p. 177) [45,55]. } \\
\text { - Offer surprise, embedded in design or "programmed } \\
\text { alterations" instead of "programmed } \\
\text { obsolescence" [55] (p. 523). } \\
\text { - Stimulate co-creation and adoption of slow } \\
\text { consumption by consumers [58]. }\end{array}$ & $\begin{array}{l}\text { - Consider registering with eco-labels for ICT, such as } \\
\text { ENERGY STAR [89], and the EU energy label EPEAT [90]. } \\
\text { - Take into account not only local but also remote energy use } \\
\text { of backbone infrastructure, such as servers or cloud } \\
\text { services [64]. During product design, decisions of whether } \\
\text { computation or storage will happen on-device or remotely } \\
\text { have to be carefully considered in regard to energy efficiency. } \\
\text { Integrate repair as a part of the product, as in the } \\
\text { Fairphone [93]. Recently the "Right to Repair" acts in the US } \\
\text { and the EU have supported consumers' right to repair and } \\
\text { maintain the products they buy, especially electronics [94]. } \\
\text { - Consider user needs and shifting of parts, e.g., if a screen is } \\
\text { needed, consider alternatives to complex touchscreens that } \\
\text { contain precious REEs, and instead use components that rely } \\
\text { on plentiful raw materials such as repaper [67]. }\end{array}$ & 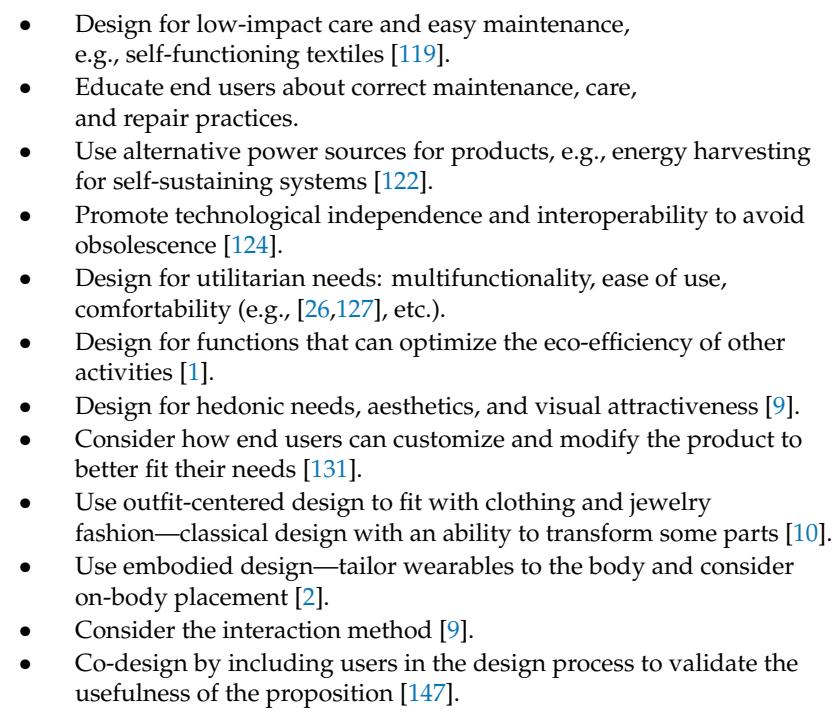 \\
\hline & 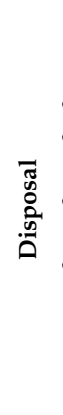 & $\begin{array}{l}\text { - Stimulate repair, mending, or recycling [59,60]. } \\
\text { - Consider organizing repair cafes to educate and } \\
\text { encourage participation of users [62]. } \\
\text { - Use sharing economy and clothes-as-service business } \\
\text { models to ensure second life of products [63]. } \\
\text { Utilize Textile Recycling Toolbox to assess } \\
\text { opportunities to contribute to a circular fashion } \\
\text { system [49]. }\end{array}$ & $\begin{array}{l}\text { - Use the "Design for Disassembly" concept, enhancing } \\
\text { recyclability of ICT [101]. } \\
\text { Apply techniques that will allow separation of } \\
\text { materials [102] as was done, for instance, in ReUse } \\
\text { project [103]. } \\
\text { - Product-service systems can remove the need for disposal. } \\
\text { Fairphone is exploring this [93]. } \\
\text { - Consider a deposit-refund system or other models that } \\
\text { incentivize the consumer to return electronics rather than } \\
\text { dispose of them (e.g., [148]). } \\
\text { Offer a trade-in program to encourage the consumer to bring } \\
\text { back older devices. Manufacturers can maintain } \\
\text { relationships with the consumer, as well [149]. }\end{array}$ & $\begin{array}{l}\text { - Consider new business models that encourage consumers to recycle } \\
\text { the product (PSS) [150]. } \\
\text { - Assist the consumer to dispose of the product properly, such as when } \\
\text { batteries or other dangerous components need special disposal [133]. } \\
\text { - Design the wearable so that not all of the product needs to be } \\
\text { disposed of, but can be reconditioned or have parts replaced-for } \\
\text { example, new watch bands can lengthen the life of the product [151]. }\end{array}$ \\
\hline
\end{tabular}




\section{Conclusions}

In this article we performed an analysis of literature across the fashion industry, ICT, and wearable technologies to understand the challenges and progress in achieving environmental sustainability goals in the product development life cycle. We gathered examples from industry, governmental organizations, NGOs, and design research to illustrate the ways in which these challenges have been addressed. While designers and product managers involved in wearable technology development may not be able to affect change across all phases in the production life cycle, we encourage these stakeholders to account for the design considerations within their control that impact environmental sustainability and to work toward the development of sustainable wearables. The results of the survey are summarized as implications for design presented in a table, with references to prototypes, research projects, and products currently on the market, illustrating specific actions and concrete examples of how designers have engaged with the respective issues.

The main audience who we envision will directly benefit from our study includes researchers, educators, developers, product managers, and design practitioners. Design practitioners will benefit from the overview of wearable technologies and will be able to examine the related projects and learn how they, too, might focus their efforts to improve the environmental sustainability of the products they develop. Researchers in the fields of design, fashion, ICT, and wearable technologies will be able to identify research areas and ongoing challenges that need additional attention and further investigation. Educators will be able to provide an overview of the latest perspectives in these fields. Design managers and product developers will be better equipped when making business decisions that involve a tradeoff between financial costs and environmental impacts.

There are certain limitations in this paper. First, sustainability is a complex and multifaceted concept, and making a clear-cut division between its three dimensions is not always possible or even desirable. Instead, the dimensions should be understood as interrelated and interconnected. Moreover, it should be taken into account that outlining sustainability guidelines is an open work in progress and, accordingly, should be updated constantly as new innovations and standards emerge and awareness and knowledge of the topic increases. Furthermore, we encountered several occasions where making a separation between the different life stages and their respective design considerations was ambiguous-for instance, in the case of material choices. However, the aim of this review was to assign the diverse themes and resulting design considerations to stages that appeared the most reasonable, according to our discussions and knowledge. The second limitation is that wearable technology is a broad category, which includes different groups of products-from textile-based technology, accessories, and jewelry to smart medical devices. There are significant differences in the life cycle processes of various groups of wearables and it would be possible to write a separate article on each group. We are taking a broader perspective on wearables-“zooming out" and such-because this approach eliminates distinct details that differentiate one category of wearables from another. Third, it should be acknowledged that our work does not provide an exhaustive survey of the existing literature, yet it does provide a comprehensive overview of the main themes, and represents an initial step in opening the discussion about the issue as well as spreading awareness among both the research community and practitioners.

For future research, we encourage continued investigation by gathering additional examples where designers have dealt with environmental sustainability challenges. It would also be beneficial to conduct interviews with practitioners and business leaders in the fashion industry and the ICT industry to understand how they deal with the changing landscape of the product development life cycle. While this paper provides an overview of key issues and examples, new technologies and processes are emerging at an increasing rate-thus, we intend to pursue a larger scale survey of the existing literature, taking input more widely from engineering and fashion journals, and to update the table of examples and implications for design. While environmental sustainability has been examined in this paper, it is important for future work to examine sustainability in a more holistic sense by combining the social and economic sustainability of wearable technologies together with the environmental perspective. 
Such work will equip stakeholders in the research community and design industry when guiding research and making informed business decisions.

Author Contributions: Funding acquisition, O.G.; Investigation, O.G., T.R.M., E.P., J.V.; Methodology, O.G., J.V.; Visualization, T.R.M., E.P.; Writing-original draft, O.G., T.R.M., E.P., J.V.; Writing—review and editing, O.G., T.R.M., E.P., J.V. All authors have read and agreed to the published version of the manuscript.

Funding: This research was funded by Talent Management program of Aalborg University, Denmark.

Conflicts of Interest: The authors declare no conflict of interest. The funders had no role in the design of the study; in the collection, analyses, or interpretation of data; in the writing of the manuscript, or in the decision to publish the results.

\section{References}

1. Köhler, A.R. Anticipatory Eco-design Strategies for Smart Textiles: Perspectives on Environmental Risk Prevention in the Development of an Emerging Technology. Ph.D. Thesis, Delft University of Technology, Delft, The Netherlands, September 2013.

2. Smelik, A.M.; Toussaint, L.; van Dongen, P. Solar fashion: An embodied approach to wearable technology. Int. J. Fash. Stud. 2016, 3, 287-303. [CrossRef]

3. Tamminen, S.; Holmgren, E. The Anthropology of Wearables: The Self, The Social, and the Autobiographical. In Proceedings of the Ethnographic Praxis in Industry Conference Proceedings (EPIC), Minneapolis, MN, USA, 29 August-1 September 2016; pp. 154-174.

4. Lupton, D. Digital Sociology, 1st ed.; Routledge: London, UK, 2014; ISBN 9781315776880.

5. Statista. Wearables. Available online: https://www.statista.com/outlook/319/100/wearables/worldwide (accessed on 7 July 2020).

6. Worldwide Wearables Market Braces for Short-Term Impact before Recovery in 2020, According to IDC. Available online: https://www.businesswire.com/news/home/20200316005755/en/Worldwide-WearablesMarket-Braces-Short-Term-Impact-Recovery (accessed on 21 September 2020).

7. Lee, J.; Kim, D.; Ryoo, H.Y.; Shin, B.S. Sustainable wearables: Wearable technology for enhancing the quality of human life. Sustainability 2016, 8, 466. [CrossRef]

8. Spil, T.A.M.; Kijl, B.; Romijnders, V. The Adoption and Diffusion of Wearables. In ICT Unbounded, Social Impact of Bright ICT Adoption. International Conference on Transfer and Diffusion of IT, TDIT (IFIP WG 8.6), Accra, Ghana, 21-22 June 2019; Dwivedi, Y., Ayaburi, E., Boateng, R., Effah, J., Eds.; Springer: Cham, Switzerland, 2019; pp. 31-47.

9. Dunne, L.E.; Profita, H.; Zeagler, C.; Clawson, J.; Gilliland, S.; Do, E.Y.; Budd, J. The Social Comfort of Wearable Technology and Gestural Interaction. In Proceedings of the 36th Annual International Conference of the IEEE Engineering in Medicine and Biology Society (EMBC'14), Chicago, IL, USA, 26-30 August 2014; pp. $4159-4162$.

10. Juhlin, O.; Zhang, Y.; Wang, J.; Andersson, A. Fashionable Services for Wearables: Inventing and Investigating a New Design Path for Smart Watches. In Proceedings of the 9th Nordic Conference on Human-computer Interaction (NordiCHI'16), Gothenburg, Sweden, 23-27 October 2016; pp. 1-10.

11. Pan, Y.; Blevis, E. Fashion Thinking. In Proceedings of the 2014 Conference on Designing Interactive Systems (DIS'14), Vancouver, BC, Canada, 21-25 June 2014; pp. 1005-1014.

12. Seymour, S. Fashionable Technology: The Intersection of Design, Fashion, Science, and Technology, 1st ed.; Springer: Vienna, Austria, 2008; ISBN 978-3-211-74498-7.

13. von Radziewsky, L.; Krüger, A.; Löchtefeld, M. Scarfy: Augmenting Human Fashion Behaviour with Self-actuated Clothes. In Proceedings of the Ninth International Conference on Tangible, Embedded, and Embodied Interaction (TEI'15), Stanford, CA, USA, 15-19 January 2015; pp. 313-316.

14. Perovich, L.; Mothersill, P.; Farah, J. Awakened Apparel. In Proceedings of the 8th International Conference on Tangible, Embedded and Embodied Interaction (TEI'14), Munich, Germany, 16-19 February 2014; pp. 77-80.

15. Bigger, E.; Fraguada, L. Programmable Plaid: The Search for Seamless Integration in Fashion and Technology. In Proceedings of the 2016 ACM International Joint Conference on Pervasive and Ubiquitous Computing (UbiComp'16), Heidelberg, Germany, 12-16 September 2016; pp. 464-469. 
16. Roinesalo, P.; Lappalainen, T.; Colley, A.; Häkkilä, J. Breaking of the Dawn Jacket: Light in the Arctic Winter. In Proceedings of the 2017 ACM International Symposium on Wearable Computers (ISWC'17), Maui, HI, USA, 11-15 September 2017; pp. 232-237.

17. Pakanen, M.; Lappalainen, T.; Roinesalo, P.; Häkkilä, J. Exploring Smart Handbag Concepts through Co-design. In Proceedings of the 15th International Conference on Mobile and Ubiquitous Multimedia (MUM'16), Rovaniemi, Finland, 12-15 December 2016; pp. 37-48.

18. Colley, A.; Pakanen, M.; Koskinen, S.; Mikkonen, K.; Häkkilä, J. Smart Handbag as a Wearable Public Display-Exploring Concepts and User Perceptions. In Proceedings of the 7th Augmented Human International Conference (AH'16), Geneva, Switzerland, 25-27 February 2016; pp. 1-8.

19. Rantala, I.; Colley, A.; Häkkilä, J. Smart Jewelry: Augmenting Traditional Wearable Self-expression Displays. In Proceedings of the 7th ACM International Symposium on Pervasive Displays (PerDis'18), Munich, Germany, 6-8 June 2018; pp. 1-8.

20. Prahl, A. Design for Circularity: Material Innovation for Wearable Technology. In Proceedings of the Circular Transitions: A Mistra Future Fashion Conference on Textile Design and the Circular Economy, London, UK, 23-24 November 2016; Goldsworthy, K., Earley, R., Eds.; pp. 285-302.

21. Passary, S. Tommy Hilfiger, Diesel, And Hugo Boss Reveal Android Wear 2.0 Smartwatches. Available online: https://www.techtimes.com/articles/203173/20170327/tommy-hilfiger-diesel-and-hugoboss-reveal-android-wear-2-0-smartwatches.htm (accessed on 14 July 2020).

22. van der Velden, N.M.; Kuusk, K.; Köhler, A.R. Life cycle assessment and eco-design of smart textiles: The importance of material selection demonstrated through e-textile product redesign. Mater. Des. 2015, 84, 313-324. [CrossRef]

23. United Nations Environment Programme. Frequently Asked Questions. Available online: https://www.unenvironment.org/explore-topics/sustainable-development-goals/why-do-sustainabledevelopment-goals-matter/frequently (accessed on 12 July 2019).

24. Elkington, J.; Trisoglio, A. Developing realistic scenarios for the environment: Lessons from Brent Spar. Long Range Plan. 1996, 29, 762-769. [CrossRef]

25. Alhaddi, H. Triple bottom line and sustainability: A literature review. Bus. Manag. Stud. 2015, 1, 6-10. [CrossRef]

26. Perry, A.; Malinin, L.; Sanders, E.; Li, Y.; Leigh, K. Explore consumer needs and design purposes of smart clothing from designers' perspectives. Int. J. Fash. Des. Technol. Educ. 2017, 10, 372-380. [CrossRef]

27. Page, T. Barriers to the adoption of wearable technology. I-Manag. J. Inf. Technol. 2015, 4, 1-13. [CrossRef]

28. Lazar, A.; Koehler, C.; Tanenbaum, J.; Nguyen, D. Why We Use and Abandon Smart Devices. In Proceedings of the 2015 ACM International Joint Conference on Pervasive and Ubiquitous Computing (UbiComp'15), Osaka, Japan, 7-11 September 2015; pp. 635-646.

29. O'Mahony, M.; Gwilt, A. Where Does Wearable Technology Fit in the Circular Economy. In Circular Transitions, A Mistra Future Fashion Conference on Textile Design and the Circular Economy; Goldsworthy, K., Earley, R., Eds.; University of the Arts London: London, UK, 23-24 November 2016; pp. 303-315.

30. Köhler, A.R. Material scarcity: A reason for responsibility in technology development and product design. Sci. Eng. Ethics 2013, 19, 1165-1179. [CrossRef]

31. Spangenberg, J.H.; Fuad-Luke, A.; Blincoe, K. Design for Sustainability (DfS): The interface of sustainable production and consumption. J. Clean. Prod. 2010, 18, 1485-1493. [CrossRef]

32. McDonough, W.; Braungart, M. Cradle to Cradle: Remaking the Way We Make Things; North Point Press: New York, NY, USA, 2010; ISBN 0-86547-587-3.

33. Stahel, W.R. The circular economy. Nat. News 2016, 531, 435-438. [CrossRef]

34. Geissdoerfer, M.; Savaget, P.; Bocken, N.M.; Hultink, E.J. The circular economy-A new sustainability paradigm? J. Clean. Prod. 2017, 143, 757-768. [CrossRef]

35. Rozas, L.W.; Klein, W.C. The value and purpose of the traditional qualitative literature review. J. Evid. Based Soc. Work 2010, 7, 387-399. [CrossRef]

36. Braun, V.; Clarke, V. Using thematic analysis in psychology. Qual. Res. Psychol. 2006, 3, 77-101. [CrossRef]

37. Bryman, A. Social Research Methods, 4th ed.; Oxford University Press: New York, NY, USA, 2012; ISBN 978-0-19-958805-3. 
38. United Nations Environment Programme, (UNEP). Putting the Breaks on Fast Fashion. Available online: https: //www.unenvironment.org/news-and-stories/story/putting-brakes-fast-fashion (accessed on 3 May 2019).

39. Global Fashion Agenda. A Call to Action for A Circular Fashion System. Available online: https://globalfashionagenda.com/wp-content/uploads/2017/04/GFA17_Call-to-action_Poluc-brief_FINAL_ 9May.pdf (accessed on 3 May 2019).

40. Lawless, E.; Medvedev, K. Assessment of sustainable design practices in the fashion industry: Experiences of eight small sustainable design companies in the Northeastern and Southeastern United States. Int. J. Fash. Des. Technol. Educ. 2016, 9, 41-50. [CrossRef]

41. Aakko, M.; Koskennurmi-Sivonen, R. Designing sustainable fashion: Possibilities and challenges. Res. J. Text. Appar. 2013, 17, 13-22. [CrossRef]

42. Alyssa Couture. The Recycled Polyester Trend and Raised Questions About Sustainability. Available online: https://consciousmagazine.co/recycled-polyester-trend-and-raised-questions-about-itssustainability/ (accessed on 2 February 2020).

43. Šajn, N. Environmental Impact of the Textile and Clothing Industry. European Parliament Research Service. Available online: http://www.europarl.europa.eu/RegData/etudes/BRIE/2019/633143/EPRS_BRI(2019)633143_ EN.pdf (accessed on 29 September 2019).

44. Fletcher, K. Slow fashion: An invitation for systems change. Fash. Pract. 2010, 2, 259-265. [CrossRef]

45. Niinimäki, K.; Hassi, L. Emerging design strategies in sustainable production and consumption of textiles and clothing. J. Clean. Prod. 2011, 19, 1876-1883. [CrossRef]

46. CFDA. Materials Index. Available online: https://cfda.com/resources/materials (accessed on 29 September 2019).

47. About BCI-Better Cotton Initiative. Available online: https://bettercotton.org/about-bci/ (accessed on 21 November 2019).

48. Global Organic Textile Standard. Available online: https://www.global-standard.org/the-standard/generaldescription.html (accessed on 10 December 2019).

49. Global Fashion Agenda Toolboxes. Available online: https://globalfashionagenda.com/commitment/ \#toolboxes (accessed on 3 July 2020).

50. Rissanen, T.; McQuillan, H. Zero Waste Fashion Design; Bloomsbury Publishing: London, UK, 2016; ISBN 1472581989.

51. EU Ecolabel: Clothing and Textiles/Textile Products. Available online: http://ec.europa.eu/ecat/category/en/ 14/textile-products (accessed on 17 December 2019).

52. Shen, B. Sustainable fashion supply chain: Lessons from H\&M. Sustainability 2014, 6, 6236-6249. [CrossRef]

53. Di Benedetto, A.C. Corporate social responsibility as emerging business model in fashion marketing. J. Glob. Fash. Mark. 2017, 8, 251-265. [CrossRef]

54. Niinimäki, K.; Koskinen, I. I love this dress, it makes me feel beautiful! Empathic knowledge in sustainable design. Des. J. 2011, 14, 165-186. [CrossRef]

55. Valle-Noronha, J. On the Agency of Clothes: Surprise as a Tool towards Stronger Engagements. In Proceedings of the 3rd Biennial Research Through Design Conference (RTD2017), Edinburgh, UK, 22-24 March 2017; pp. 519-534.

56. Fletcher, K.; Klepp, I.G. Opening Up the Wardrobe: A Methods Book; Novus Press: Oslo, Norway, 2017; ISBN 978-82-7099-893-7.

57. Valle-Noronha, J.; Niinimäki, K.; Kujala, S. Notes on wearer-worn attachments: Learning to wear. Cloth. Cult. 2018, 5, 225-246. [CrossRef]

58. Jung, S.; Jin, B. A theoretical investigation of slow fashion: Sustainable future of the apparel industry. Int. J. Consum. Stud. 2014, 38, 510-519. [CrossRef]

59. Gwilt, A. What prevents people repairing clothes? An investigation into community-based approaches to sustainable product service systems for clothing repair. Mak. Futures J. 2014, 3. Available online: http://shura.shu.ac.uk/8125/1/Gwilt__Alison.pdf (accessed on 24 July 2020).

60. Durrani, M. "People gather for stranger things, so why not this?" Learning sustainable sensibilities through communal garment-mending practices. Sustainability 2018, 10, 2218. [CrossRef]

61. Middleton, J. Mending. In Routledge Handbook of Sustainability and Fashion; Fletcher, K., Tham, M., Eds.; Routledge: London, UK, 2014; pp. 280-292. 
62. Graziano, V.; Trogal, K. The politics of collective repair: Examining object-relations in a postwork society. Cult. Stud. 2017, 31, 634-658. [CrossRef]

63. Nurmi, A. "Clothes as a service" will disrupt the fashion system. In Sustainable Fashion in a Circular Economy; Niinimäki, K., Ed.; Aalto University: Helsinki, Finland, 2018; pp. 236-240. ISBN 978-952-60-0089-3.

64. Belkhir, L.; Elmeligi, A. Assessing ICT global emissions footprint: Trends to 2040 \& recommendations. J. Clean. Prod. 2018, 177, 448-463. [CrossRef]

65. Wäger, P.A.; Hischier, R.; Widmer, R. The material basis of ICT. In ICT Innovations for Sustainability; Advances in Intelligent Systems and Computing 310; Hilty, L., Aebischer, B., Eds.; Springer: Cham, Switzerland, 2015; pp. 209-221. ISBN 978-3-319-09227-0.

66. Hilty, L.M.; Lohmann, W. The five most neglected issues in "Green IT". Cepis Upgrad. Eur. J. Inform. Prof. 2011, 12, 11-15.

67. Graedel, T.E.; Harper, E.M.; Nassar, N.T.; Reck, B.K. On the materials basis of modern society. Proc. Natl. Acad. Sci. USA 2015, 112, 6295-6300. [CrossRef] [PubMed]

68. Mueller, S.R.; Wäger, P.A.; Widmer, R.; Williams, I.D. A geological reconnaissance of electrical and electronic waste as a source for rare earth metals. Waste Manag. 2015, 45, 226-234. [CrossRef]

69. Izatt, R.M.; Izatt, S.R.; Bruening, R.L.; Izatt, N.E.; Moyer, B.A. Challenges to achievement of metal sustainability in our high-tech society. Chem. Soc. Rev. 2014, 43, 2451-2475. [CrossRef]

70. Telenko, C.; Seepersad, C.C.; Webber, M.E. A Compilation of Design for Environment Principles and Guidelines. In Proceedings of the International Design Engineering Technical Conferences and Computers and Information in Engineering Conference (IDETC/CIE2008), Brooklyn, NY, USA, 3-6 August 2008; pp. 289-301.

71. Gross, R.A.; Kalra, B. Biodegradable polymers for the environment. Science 2002, 297, 803-807. [CrossRef]

72. Frenzel, M.; Tolosana-Delgado, R.; Gutzmer, J. Assessing the supply potential of high-tech metals-A general method. Resour. Policy 2015, 46, 45-58. [CrossRef]

73. Ali, S.H.; Giurco, D.; Arndt, N.; Nickless, E.; Brown, G.; Demetriades, A.; Durrheim, R.; Enriquez, M.A.; Kinnaird, J.; Littleboy, A.; et al. Mineral supply for sustainable development requires resource governance. Nature 2017, 543, 367-372. [CrossRef] [PubMed]

74. Blengini, G.A.; Nuss, P.; Dewulf, J.; Nita, V.; Peirò, L.T.; Vidal-Legaz, B.; Latunussa, C.; Mancini, L.; Blagoeva, D.; Pennington, D.; et al. EU methodology for critical raw materials assessment: Policy needs and proposed solutions for incremental improvements. Resour. Policy 2017, 53, 12-19. [CrossRef]

75. Communication from the Commission to the European Parliament, the Council, the European Economic and Social Committee and the Committee of the Regions on the 2017 List of Critical Raw Materials for the EU. Available online: http://eur-lex.europa.eu/legal-content/EN/TXT/HTML/?uri=CELEX:52017DC0490\&from= EN (accessed on 4 December 2019).

76. Quariguasi Frota Neto, J.; Walther, G.; Bloemhof, J.; van Nunen, J.A.E.E.; Spengler, T. From closed-loop to sustainable supply chains: The WEEE case. Int. J. Prod. Res. 2010, 48, 4463-4481. [CrossRef]

77. Quariguasi Frota Neto, J.; Bloemhof, J. An analysis of the eco-efficiency of remanufactured personal computers and mobile phones. Prod. Oper. Manag. 2012, 21, 101-114. [CrossRef]

78. Hunt, C.P.; Wickham, M.; Pittson, R.; Lewison, J. Reusable, Unzippable, Sustainable Electronics (ReUse) Interconnect System for the Circular Economy. Report for NPL, MAT 75. 2 February 2018. Available online: http://eprintspublications.npl.co.uk/6645/ (accessed on 24 July 2020).

79. Kasser, U.; Pöll, M.; Graffe, K. Ökologische Bewertung mit Hilfe der Grauen Energie; Bundesamt für Umwelt, Wald und Landschaft (BUWAL): Bern, Switzerland, 1999.

80. Hischier, R.; Coroama, V.C.; Schien, D.; Achachlouei, M.A. Grey energy and environmental impacts of ICT hardware. In ICT Innovations for Sustainability; Advances in Intelligent Systems and Computing 310; Hilty, L., Aebischer, B., Eds.; Springer: Cham, Switzerland, 2015; pp. 171-189. ISBN 978-3-319-09227-0.

81. Köhler, A.; Erdmann, L. Expected environmental impacts of pervasive computing. Hum. Ecol. Risk Assess. Int. J. 2004, 10, 831-852. [CrossRef]

82. Plepys, A. The grey side of ICT. Environ. Impact Assess. Rev. 2002, 22, 509-523. [CrossRef]

83. EU Directive 2002/95/EC of the European Parliament and of the Council of 27 January 2003 on the restriction of the use of certain hazardous substances in electrical and electronic equipment. Off. J. Eur. Union 2003, 13, 19-23. 
84. US EPA. Sustainable Materials Management (SMM) Electronics Challenge. Available online: https:// www.epa.gov/smm-electronics/sustainable-materials-management-smm-electronics-challenge (accessed on 27 September 2019).

85. Patrignani, N.; Whitehouse, D. Slow Tech and ICT: A Responsible, Sustainable and Ethical Approach; Springer: Cham, Switzerland, 2017; ISBN 978-3-319-68943-2.

86. Greenpeace. Guide to Greener Electronics. Available online: https://www.greenpeace.org/usa/reports/ greener-electronics-2017/ (accessed on 18 July 2019).

87. Roy, R. Sustainable product-service systems. Futures 2000, 32, 289-299. [CrossRef]

88. Doualle, B.; Medini, K.; Boucher, X.; Brissaud, D.; Laforest, V. Design of sustainable product-service systems (PSS): Towards an incremental stepwise assessment method. Procedia CIRP 2016, 48, 152-157. [CrossRef]

89. EnergyStar. The Simple Choice for Energy Efficiency. Available online: https://www.energystar.gov/ (accessed on 8 December 2019).

90. Green Electronics Council. EPEAT for Manufacturers. Available online: https:/greenelectronicscouncil.org/ epeat/manufacturers/ (accessed on 4 December 2019).

91. Newman, J. 6 Things You'd Never Guess About Google's Energy Use. Available online: http://techland.time. com/2011/09/09/6-things-youd-never-guess-about-googles-energy-use/ (accessed on 19 November 2019).

92. Preist, C.; Schien, D.; Shabajee, P. Evaluating Sustainable Interaction Design of Digital Services. In Proceedings of the 2019 CHI Conference on Human Factors in Computing Systems (CHI 2019), Glasgow, UK, 4-9 May 2019; pp. 1-12.

93. Lomas, Natasha. Can Fairphone 3 Scale Ethical Consumer Electronics? Available online: https:/techcrunch. com/2019/08/27/can-fairphone-3-scale-ethical-consumer-electronics/ (accessed on 11 October 2020).

94. The Repair Association. Available online: https://repair.org (accessed on 21 November 2019).

95. Böni, H.; Schluep, M.; Widmer, R. Recycling of ICT equipment in industrialized and developing countries. ICT Innov. Sustain. 2015, 223-241. [CrossRef]

96. Williams, E. Environmental effects of information and communications technologies. Nature 2011, 479, 354-358. [CrossRef] [PubMed]

97. Kahhat, R.; Williams, E. Materials flow analysis of e-waste: Domestic flows and exports of used computers from the United States. Resour. Conserv. Recycl. 2012, 67, 67-74. [CrossRef]

98. Oswald, I.; Reller, A. E-waste: A story of trashing, trading, and valuable resources. Gaia-Ecol. Perspect. Sci. Soc. 2011, 20, 41-47. [CrossRef]

99. Chi, X.; Streicher-Porte, M.; Wang, M.Y.L.; Reuter, M.A. Informal electronic waste recycling: A sector review with special focus on China. Waste Manag. 2011, 31, 731-742. [CrossRef]

100. Williams, E.; Kahhat, R.; Allenby, B.; Kavazanjian, E.; Kim, J.; Xu, M. Environmental, social, and economic implications of global reuse and recycling of personal computers. Environ. Sci. Technol. 2008, 42, 6446-6454. [CrossRef]

101. Boothroyd, G.; Alting, L. Design for assembly and disassembly. CIRP Ann. Manuf. Technol. 1992, 41, $625-636$. [CrossRef]

102. Platcheck, E.R.; Schaeffer, L.; Kindlein, W.; Cãndido, L.H.A. Methodology of ecodesign for the development of more sustainable electro-electronic equipments. J. Clean. Prod. 2008, 16, 75-86. [CrossRef]

103. National Physical Laboratory. Recyclable Electronics: Just Add Hot Water. Available online: https: //phys.org/news/2012-06-recyclable-circuit-boards.html (accessed on 27 September 2019).

104. Ossevoort, S.H.W. Improving the sustainability of smart textiles. In Multidisciplinary Know-How for Smart-Textiles Developers; Kirstein, T., Ed.; Woodhead Publishing: Cambridge, UK, 2013; pp. 399-419.

105. Fleischmann, K.; Hielscher, S.; Merritt, T. Making things in Fab Labs: A case study on sustainability and co-creation. Digit. Creat. 2016, 27, 113-131. [CrossRef]

106. Yao, L.; Ou, J.; Cheng, C.; Steiner, H.; Wang, W.; Wang, G.; Ishii, H. bioLogic: Natto Cells as Nanoactuators for Shape Changing Interfaces. In Proceedings of the 33rd Annual ACM Conference on Human Factors in Computing Systems (CHI'15), Seoul, Korea, 18-23 April 2015; pp. 1-10. 
107. Flores, R. Scientists Create Biodegradable, Paper-based Biobatteries. Available online: https://www. binghamton.edu/news/story/1227/scientists-create-biodegradable-paper-based-biobatteries (accessed on 16 August 2019).

108. Bourzac, K. Biodegradable Batteries to Power Smart Medical Devices. Available online: https://www. technologyreview.com/s/522581/biodegradable-batteries-to-power-smart-medical-devices/ (accessed on 26 July 2016).

109. Goncu-Berk, G. Smart Textiles and Clothing: An Opportunity or A Threat for Sustainability? In Proceedings of the Textile Intersections 2019, Loughborough, UK, 12-14 September 2019. [CrossRef]

110. Tseng, M.; Chiu, S.F.; Tan, R.R.; Siriban-Manalang, A.B. Sustainable consumption and production for Asia: Sustainability through green design and practice. J. Clean. Prod. 2013, 40,1-5. [CrossRef]

111. Timmins, M. Environmental and waste issues concerning the production of smart clothes and wearable technology. In Smart Clothes and Wearable Technology; McCann, J., Bryson, D., Eds.; Woodhead Publishing: Cambridge, UK, 2009; pp. 319-331.

112. Prahl, A. Designing Wearable Sensors for Preventative Health: An Exploration of Material, Form and Function. Ph.D. Thesis, University of the Arts London, London, UK, September 2015.

113. Buechley, L.; Eisenberg, M. The LilyPad Arduino: Toward wearable engineering for everyone. Pervasive Comput. 2008, 7, 12-15. [CrossRef]

114. Adafruit. Getting Started with FLORA. Available online: https://learn.adafruit.com/getting-started-withflora/flora-projects (accessed on 21 November 2019).

115. Flex-Ability. An E-textile Interface Kit for Persons with Limited Mobility. Available online: http://flex-ability. org/ (accessed on 7 December 2019).

116. Chen, D.; Heyer, S.; Ibbotson, S.; Salonitis, K.; Steingrímsson, J.G.; Thiede, S. Direct digital manufacturing: Definition, evolution, and sustainability implications. J. Clean. Prod. 2015, 107, 615-625. [CrossRef]

117. Raasch, C.; Herstatt, C.; Balka, K. On the open design of tangible goods. RD Manag. 2009, 39, 382-393. [CrossRef]

118. Bonvoisin, J. Implications of Open Source Design for Sustainability. In Proceedings of the 3d International Conference on Sustainable Design and Manufacturing (SDM'16), Chania, Greece, 4-6 April 2016; pp. 45-59.

119. Li, L.; Cheung, T.W. Sustainable development of smart textiles: A review of 'self-functioning' abilities which makes textiles alive. J. Text. Eng. Fash. Technol. 2018, 4, 151-156. [CrossRef]

120. Brutten, M. Nano-Tex introduces Fortify DP: An Innovation in Wrinkle-Free Technology. Report for Nano-Tex Company. 29 September 2011. Available online: https://www.textileweb.com/doc/nano-tex-introducesfortify-dp-an-innovation-0001 (accessed on 13 October 2020).

121. Roinesalo, P.; Virtanen, L.; Lappalainen, T.; Kylmänen, A.; Häkkilä, J. Solar Shirt: Design of an Environmental Awareness Wearable. In Proceedings of the 2016 ACM International Joint Conference on Pervasive and Ubiquitous Computing (UbiComp'16), Heidelberg, Germany, September 2016; pp. 495-499.

122. Thielen, M.; Sigrist, L.; Magno, M.; Hierold, C.; Benini, L. Human body heat for powering wearable devices: From thermal energy to application. Energy Convers. Manag. 2017, 131, 44-54. [CrossRef]

123. Wang, J.; Li, S.; Yi, F.; Zi, Y.; Lin, J.; Wang, X.; Xu, Y.; Wang, Z.L. Sustainably powering wearable electronics solely by biomechanical energy. Nat. Commun. 2016, 7, 12744. [CrossRef] [PubMed]

124. Kuusk, K. Crafting Sustainable Smart Textile Services. Ph.D. Thesis, Technische Universiteit, Eindhoven, The Netherlands, February 2016.

125. Juhlin, O.; Zhang, Y. Unpacking Social Interaction that Make Us Adore: On the Aesthetics of Mobile Phones as Fashion Items. In Proceedings of the 13th International Conference on Human Computer Interaction with Mobile Devices and Services (MobileHCI'11), Stockholm, Sweden, 30 August-2 September 2011; pp. 241-250.

126. Fernández-Caramés, T.; Fraga-Lamas, P. Towards the Internet of smart clothing: A review on IoT wearables and garments for creating intelligent connected e-textiles. Electronics 2018, 7, 405. [CrossRef]

127. Fortmann, J.; Root, E.; Boll, S.; Heuten, W. Tangible Apps Bracelet: Designing Modular Wrist-worn Digital Jewelry for Multiple Purposes. In Proceedings of the 2016 ACM Conference on Designing Interactive Systems (DIS'16), Brisbane, Australia, 4-8 June 2016; pp. 841-852.

128. Hilty, L.M.; Wäger, P.; Lehmann, M.; Hischier, R.; Ruddy, T.F.; Binswanger, M. The Future Impact of ICT on Environmental Sustainability. Fourth Interim Report. Refinement and Quantification. Institute for Prospective Technological Studies, Sevilla 2004. Available online: https:/ec.europa.eu/digital-single-market/en/news/ future-impact-icts-environmental-sustainability (accessed on 24 July 2020). 
129. Galloway, A.; Brucker-Cohen, J.; Gaye, L.; Goodman, E.; Hill, D. Design for Hackability. In Proceedings of the 5th Conference on Designing Interactive Systems (DIS'04), Cambridge, MA, USA, 1-4 August 2004; pp. 363-366.

130. Pateman, M.; Harrison, D.; Marshall, P.; Cecchinato, M.E. The Role of Aesthetics and Design: Wearables In Situ. In Proceedings of the Extended Abstracts of the 2018 CHI Conference on Human Factors in Computing Systems (CHI'18), Montreal, QC, Canada, 21-26 April 2018; pp. 1-6.

131. Koo, H.; Dunne, L.; Bye, E. Design functions in transformable garments for sustainability. Int. J. Fash. Des. Technol. Educ. 2013, 7, 10-20. [CrossRef]

132. Harrison, C.; Lim, B.; Shick, A.; Hudson, S. Where to Locate Wearable Displays? Reaction Time Performance of Visual Alerts from Tip to Toe. In Proceedings of the SIGCHI Conference on Human Factors in Computing Systems (CHI'09), Boston, MA, USA, 4-9 April 2009; pp. 941-944.

133. Köhler, A.R.; Hilty, L.M.; Bakker, C. Prospective impacts of electronic textiles on recycling and disposal. J. Ind. Ecol. 2011, 15, 496-511. [CrossRef]

134. Ogunseitan, O.A.; Schoenung, J.M.; Saphores, J.D.M.; Shapiro, A.A. The electronics revolution: From e-wonderland to e-wasteland. Science 2009, 326, 670-671. [CrossRef]

135. Bovea, M.D.; Ibáñez-Forés, V.; Pérez-Belis, V.; Quemades-Beltrán, P. Potential reuse of small household waste electrical and electronic equipment: Methodology and case study. Waste Manag. 2016, 53, 204-217. [CrossRef] [PubMed]

136. Höök, K.; Löwgren, J. Strong concepts: Intermediate-level knowledge in interaction design research. Acm Trans. Comput. Hum. Interact. 2012, 19, 1-18. [CrossRef]

137. Sas, C.; Whittaker, S.; Dow, S.; Forlizzi, J.; Zimmerman, J. Generating Implications for Design through Design Research. In Proceedings of the SIGCHI Conference on Human Factors in Computing Systems (CHI'14), Toronto, ON, Canada, 26 April 2014; pp. 1971-1980.

138. Dourish, P. Implications for Design. In Proceedings of the SIGCHI Conference on Human Factors in Computing Systems (CHI 2006), Montréal, QC, Canada, 22-27 April 2006; pp. 541-550.

139. SparkFun Sustainability Effort. Available online: https://www.sparkfun.com/news/794 (accessed on 27 September 2019).

140. Digi-Key Environmental—Conservation, Education \& Waste Reduction. Available online: https://www. digikey.com/en/resources/environmental/initiative (accessed on 27 September 2019).

141. Fly Dragon Initiative Material Change Report. Available online: https:/www.thedragonflyinitiative.com/ material-change-report (accessed on 27 September 2019).

142. US EPA. Identifying Greener Electronics. Overviews and Factsheets. Available online: https://www.epa.gov/ greenerproducts/identifying-greener-electronics (accessed on 27 September 2019).

143. Protolabs. Injection Moulding, Rapid Prototyping, 3D Printing, CNC. Available online: https://www. protolabs.co.uk/ (accessed on 17 December 2019).

144. Bar-Cohen, A.; Iyengar, M. Design and optimization of air-cooled heat sinks for sustainable development. Ieee Trans. Compon. Packag. Technol. 2002, 25, 584-591. [CrossRef]

145. Studio HILO. What We Do. Available online: https://www.studiohilo.com/what-we-offer (accessed on 21 November 2019).

146. United Nations Environment Programme (UNEP). Metal Stocks in Society: Scientific Synthesis. Metal Stocks in Society: Scientific. 2011. Available online: http://wedocs.unep.org/handle/20.500.11822/8438 (accessed on 24 July 2020).

147. Cherenack, K.; van Pieterson, L. Smart textiles: Challenges and opportunities. J. Appl. Phys. 2012, $112,91301$. [CrossRef]

148. Fullerton, D.; Wolverton, A. Two generalizations of a deposit-refund system. Am. Econ. Rev. 2000, 90, $238-242$. [CrossRef]

149. Consumer Reports. What You Need to Know about Electronics Trade-in Programs. Available online: https://www.consumerreports.org/cro/news/2013/09/electronics-trade-in-programs/index.htm (accessed on 7 September 2019). 
150. Kuusk, K.; Niinimäki, K.M.; Wensveen, S.A.G.; Tomico Plasencia, O. Smart Textile Products and Services in Sustainability Context. In Proceedings of the Ambience14\&10i3m, Scientific Conference for Smart and Functional Textiles, Well-Being, Thermal Comfort in Clothing, Design, Thermal Manikins and Modelling, Tampere, Finland, 7-9 September 2014; Available online: https://www.researchgate.net/profile/Kristi_ Kuusk/publication/299377389_Smart_Textile_Products_and_Services_in_Sustainability_Context/links/ 56f2b0e308aea5a8982ff961/Smart-Textile-Products-and-Services-in-Sustainability-Context.pdf (accessed on 24 July 2020).

151. Pan, Y.; Roedl, D.; Blevis, E.; Thomas, J. Fashion thinking: Fashion practices and sustainable interaction design. Int. J. Des. 2015, 9, 53-66. [CrossRef]

Publisher's Note: MDPI stays neutral with regard to jurisdictional claims in published maps and institutional affiliations.

(C) 2020 by the authors. Licensee MDPI, Basel, Switzerland. This article is an open access article distributed under the terms and conditions of the Creative Commons Attribution (CC BY) license (http://creativecommons.org/licenses/by/4.0/). 